\title{
Low Prevalence of Hepatitis B and C Markers in a Non-Amazonian Indigenous Population
}

\begin{abstract}
José Ivan Aguiar, Juberty Antonio de Souza, Eliana Setti Aguiar, Jaqueline M. Oliveira, Elba R. S. de Lemos and Clara F. T. Yoshida
\end{abstract}

In Brazil, there is a high prevalence of markers of infection with the hepatitis $B$ virus among groups living in the Western Amazon. Neighboring countries and indigenous peoples should also be included in that context [1-6].

There are virtually no data available on the prevalence of viral hepatitis markers among indigenous groups living outside the Amazon region or about parenterally transmitted hepatitis.

Figueiredo et al. [7] reported the prevalence of HBV and HCV markers among the native Xacriabá people living in the northern part of the State of Minas Gerais; they found $0.5 \%, 2.9 \%, 62.5$, and $0.5 \%$ for $\mathrm{HBsAg}$, anti-HBc, anti-HBs and anti-HCV, respectively. This group is just as acculturated as the Terena and has a long history of contact with modern Brazilian society.

To assess this situation, a sero-epidemiological study was conducted in August 1999, involving 312 Amerindians from the Buriti, Córrego do Meio and Água Azul reservations, located in the municipalities of Sidrolândia and Dois Irmãos do Buriti, 100km from Campo Grande, the state capital of Mato Grosso do Sul (Brazil). The samples were randomly selected, and family groups were included.

This study included all age groups, from children under 1 year to individuals older than 65 . Each age group was stratified according to gender (Table 1).

Received on 10 May 2002; revised 07 August 2002. Address for correspondence: Dr. José Ivan Aguiar, Rua Amazonas 1376, Vila Rosa, Zip Code: 79010-060 Campo Grande-MS/Brazil.

Phone: +55 67 351-0531. E-mail joseivan@brturbo.com

The Brazilian Journal of Infectious Diseases 2002;6(5):269-270 (C) 2002 by The Brazilian Journal of Infectious Diseases and Contexto Publishing. All rights reserved.

$1413-8670$
Federal University of Mato Grosso do Sul, Ms/Brazil, Oswaldo Cruz Foundation, RJ, Brazil

The material was collected, centrifuged, and separated into varying aliquots. Tests for anti-HBc, anti HBs and anti-HCV markers were conducted at the Oswaldo Cruz Foundation (Fiocruz-RJ) National Viral Hepatitis Center. There were small differences in the number of tests for each marker due to limitations in the quantity of material.

None of the samples were positive for HBsAg or anti-HCV. Anti-HBc gave positive results in $2.2 \%$ of the samples and anti-HBs in $13.6 \%$. The high percentage found for anti-HBs positivity could be a result of immunity that was artificially acquired through vaccination.

We found very low positivity rates for the above markers in this population. There are discrepancies between our data and findings previously reported for the same region. Aguiar et al. [8] found prevalence rates of $0.7 \%, 9.4 \%$ and $2.5 \%$ for $\mathrm{HBsAg}$, anti-HBc and anti-HCV, respectively among first-time donors in Campo Grande. In a study of people of African descent living $65 \mathrm{~km}$ from Campo Grande and $40 \mathrm{~km}$ from the municipality of Jaraguari (Mato Grosso do Sul), Castro [9] found rates of $9 \%$ and $43 \%$ for HBsAg and anti$\mathrm{HBc}$, respectively.

These variations in prevalence need to be better explained; it may be necessary to use an approach involving other components. Authors such as Brabin et al. [10], Passos et al. [11], and Coimbra et al. [12] have suggested that other variables can influence HBV prevalence rates, which would mean that a simple epidemiological model of this disease is not realistic.

It is sometimes necessary to take into account pecularities of certain population groups in which different values, norms and cultural standards may be involved in health/illness processes [13]. 
Table 1. Breakdown of the Amerindian population from the Buriti, Córrego do Meio and Água Azul reservations tested for viral hepatitis in August 1999, divided by age group and gender

\begin{tabular}{ccrr}
\hline \multirow{2}{*}{ Age Group } & \multicolumn{2}{c}{ No. (\%) } \\
\cline { 2 - 3 } & \multicolumn{2}{c}{ Gender } & \\
\cline { 2 - 3 } & Male & Female & Total \\
\hline $0-4$ & $10(41.7)$ & $14(58.3)$ & 24 \\
$5-9$ & $29(49.1)$ & $30(50.9)$ & 59 \\
$10-19$ & $44(46.3)$ & $51(53.7)$ & 95 \\
$20-44$ & $23(31.9)$ & $49(68.1)$ & 72 \\
$45-64$ & $18(47.3)$ & $20(52.7)$ & 38 \\
65 & $13(54.2)$ & $11(45.8)$ & 24 \\
Total & 137 & 175 & 312 \\
\hline
\end{tabular}

\section{References}

1. Gayotto L.C.C., Quarentei A.A., Cabral G.L. Soroepidemiology of hepatitis A and B in two areas of the West Amazon. GED 1984;3:106-12.

2. Bensabath G., Hadler S.C., Soares Pereira M.C., et al. Características serologicas y epidemiológicas de la hepatitis virica aguda en la cuenca amazônica del Brasil. Bol of Sanit Panam 1987; 103:351-62.

3. Fonseca J.C.F., Simonetti S.R.R., Schatzmayr H.C., et al. Prevalence of infection with hepatitis delta virus among carriers of hepatitis B surface antigen in Amazonas State, Brazil. Transactions of the Royal Society of Tropical Medicine and Hygiene 1988;82:469-71.

4. Restrepo FH, Duran MM, Gamarra AI, Velandia MP, Rojas MC. Factores de riesgo en la transmission de la hepatitis B en la amazonia colombiana. Biomedia; 1992; $12: 5-9$.

5. Santos A.K.C.R., Iskah M.O.G., Santos S.E.B., Guereiro J.F., Ishak R. A possible correlation between the host genetic background in the epidemiology of hepatitis B virus in the amazon region of Brazil. Mem Inst Oswaldo Cruz 1995; 90 :435-41.

6. Souto F.J.D., Fontes C.J.F., Gaspar A.M.C., et al. Concomitant high prevalence of hepatitis $\mathrm{C}$ virus antibodies and hepatitis virus markers in a small village of the amazon region, Mato Grosso State, Brazil. Rev Inst Med Trop S Paulo 1996;38:221-3.

7. Figueiredo J.F.C., Machado A.A., Martinez R., et al. Prevalências das infeções pelos vírus, anticorpos e hepatites B e C na Reserva Indígena Xacriabá, MG, Brasil. Rev Soc Bras Med Trop 2000;33:211.
8. Aguiar J.I., Aguiar E., Paniago A., et al. Prevalence of Antibodies to hepatitis B core Antigen in Blood Donors in the Middle West Region of Brazil. Mem Inst Oswaldo Cruz 2001;96:185-7.

9. Castro A.R.C.M. Estudo da Prevalência da hepatite B em afro-descendentes da comunidade de Furnas dos Dionísios - MS. Campo Grande, 2000.130 p. Msc. Thesis - IOC-FIOCRUZ/UFMS.

10. Brabin L., Brabin BJ. Cultural factors and transmission of hepatitis B Virus. Am J Epidemiol 1985; 122:725-30.

11. Passos A.D.C., Gomes U.A., Figueredo J.F.C., et al. Prevalência de marcadores sorológicos de hepatite $\mathrm{B}$ numa pequena comunidade rural do Estado de São Paulo. Rev Saúde Pública, São Paulo 1992;26:119-24.

12. Coimbra Jr C.E.A., Santos, R.V., Yoshida C.F.Y., et al. Hepatitis B Epidemiology and Cultural Practices In Amerindian Populations of Amazônia: The TupiMondé and the Xavante from Brazil. Soc Sci Med 1996;42:1735-43.

13. Ishida T., Takao S., Settheetham-Ishida W., Tiwawech D. Prevalence of hepatitis B and C Virus infection in rural ethnic populations of Northern Thailand. Journal of Clinical Virology 2002;24:31-5. 